\title{
En busca de interacciones fructíferas entre las empresas multinacionales del turismo y los gobiernos locales en África
}

\author{
Antonia Mercedes García-Cabrera ${ }^{\mathrm{a}, 1}$, Sonia María Suárez-Ortega ${ }^{a}$, Juan José Durán-Herrerab \\ ${ }^{a}$ Universidad de Las Palmas de Gran Canaria (ULPGC), España \\ ${ }^{b}$ Universidad Autónoma de Madrid, España
}

doi: 10.20420/eni.2018.215

\begin{abstract}
Resumen
En el estudio de la internacionalización hacia países en desarrollo de la empresa turística radicada en países desarrollados frecuentemente se analizan los retos que tal internacionalización comporta a los dos partes implicadas -la empresa turística extrajera y la comunidad local-, y desde dos perspectivas diferentes: (1) los retos que las multinacionales turísticas afrontan para operar con éxito en un país africano, y (2) los problemas concretos afrontados por las autoridades y la población local debido a las actividades llevadas a cabo por las multinacionales turísticas. Dado que una relación fructífera entre ambas partes puede ser muy beneficiosa, en este trabajo vamos más allá de las perspectivas de análisis individualizadas para tratar de responder a las dos cuestiones siguientes: (i) ¿cuáles son los mecanismos disponibles para que la empresa turística interactúe con las autoridades locales y los posibles efectos de éstos?; y (ii) ¿cuáles son los factores clave que facilitan una interacción de éxito con el gobierno de un país africano? Respondemos a estas preguntas a partir del estudio de un caso.
\end{abstract}

Palabras clave: empresas multinacionales, economías en desarrollo, África, turismo, interacciones empresa-gobierno.

Clasificación JEL: F23, N27, Z32.

Agradecimientos: Los autores agradecen el apoyo financiero proporcionado por el Ministerio de Economía y Competitividad (Proyectos: ECO2013-41762-P; ECO2016-80518-R).

Fuente de referencia: García-Cabrera, A.M., Suárez-Ortega, S.M., \& Durán-Herrera, J.J. (2016). Multinational corporations, co-evolution, and sustainable tourism in Africa. European Journal of Tourism Research, 13, 23-42.

\section{Introducción}

La internacionalización hacia países en desarrollo de empresas turísticas radicadas en países desarrollados es un tema de elevado interés para el sector. Mientras que algunos analistas han destacado los retos que afronta la empresa cuando entra en una economía con instituciones débiles, otros han analizado el daño generado por tales empresas en términos sociales, culturales y medioambientales. De esta forma, prestar atención solo a una de estas dos partes del problema conlleva el riesgo de ser sesgados en los análisis, de manera que difícilmente se puede contribuir a responder a los retos que cada parte afronta en el proceso.

De hecho, diversos casos reales muestran la existencia de relaciones caracterizadas por las desavenencias entre las empresas foráneas y los actores locales. Por una parte, las empresas multinacionales son muchas veces responsables del fracaso en las relaciones con las autoridades locales debido a los métodos que utilizan para operar en tales países, así como por su superioridad relativa en términos de poder, de la que en ocasiones hacen gala. Por otra parte, las multinacionales entrantes también hacen frente a desafíos de importancia, como la intervención del gobierno local, que en muchos casos perjudica la libre competencia, al tiempo que genera la necesidad de interactuar y relacionarse con las autoridades locales de forma continua para operar en el sector.

Estos problemas han sido dados por indiscutibles en el pasado, de forma que solo recientemente los gobiernos y las empresas han

${ }^{1}$ Autor de correspondencia: antonia.garcia@ulpgc.es 
comenzado a superar tales planteamientos para explorar las oportunidades conjuntas derivadas del desarrollo del turismo sostenible, 'a favor de los pobres' (Fortanier \& Wijk, 2010).

De esta forma, admitiendo que los problemas afectan a los dos lados, pero también que existen oportunidades económicas que pueden surgir de una interacción adecuada (Zhao \& Ritchie, 2007), el presente trabajo analiza los procesos y factores que condicionan tales interacciones. Concretamente, se pretende responder a las siguientes cuestiones: (1) ¿A qué retos específicos hace frente la multinacional turística cuando opera en un país africano en desarrollo?; (ii) ¿Cuáles son los problemas que afronta al interactuar con las autoridades locales?; (iii) ¿Qué mecanismos puede utilizar la empresa turística para interactuar con las autoridades locales y qué efectos derivan de éstos?; y (iv) ¿Cuáles son los factores clave que facilitan una interacción de éxito con el gobierno en un país africano en desarrollo?

\section{Interacciones entre empresas multinacionales y gobiernos: los factores condicionantes}

Las empresas y sus entornos pueden condicionarse mutuamente a lo largo del tiempo como consecuencia de la influencia bidireccional existente entre las decisiones de los directivos y las de los gobiernos (Madhok \& Liu, 2006). Ahora bien, la forma en que tales interacciones se producen y los factores clave que las condicionan son prácticamente desconocidos.

De acuerdo con los principios de la Teoría evolutiva, las acciones adoptadas por las empresas turísticas, tales como la innovación y su transferencia, generan una evolución del entorno (Brouder \& Eriksson, 2013). Ahora bien, en contextos en los que cabe esperar resultados adversos (e.g., crisis económica, dificultades en economías en desarrollo), las empresas pueden tener un incentivo para promover en el entorno cambios que les beneficien, y así mejorar su competitividad. A este respecto, las empresas pueden actuar sobre los gobiernos para conseguir los cambios que les interesan.

Es más, las empresas pueden voluntariamente implicarse en interacciones y/o relaciones de conflicto para prevenir/impedir que los cambios indeseados se produzcan (Khavul, Chavez \& Bruton, 2013). Por ejemplo, en aquellos casos en que los gobiernos desean impulsar cambios para combatir los problemas económicos de un país, si las empresas entienden que a ellas les afectan negativamente, podrían actuar tratando de impedir tales cambios.

Ahora bien, existen dos amplias categorías de condiciones que afectan a los procesos de interacción que se producen entre las empresas y los gobiernos:

(1) Condiciones referidas a los actores, esto es, recursos de los que disponen y que permiten ejercer influencia sobre el gobierno. Por ejemplo, el poder económico de éstas y la rentabilidad generada en el país de destino de su inversión. Además, capacidades tales como la flexibilidad para actuar y reaccionar a los cambios que tienen lugar en el entorno, o la habilidad para movilizar recursos internos y apoyos externos para influir sobre el entorno son también de relevancia. A ello se une la ideología de la empresa, esto es, sus valores de responsabilidad social, así como la disposición de ésta para utilizar sus bases de poder económico para influir en las autoridades. Además, las multinacionales también precisan de recursos sociales y habilidades de negociación al objeto de interactuar con las autoridades locales ya que, como actores únicos, pueden fracasar en su intento de influir sobre el gobierno y promover cambios en el entorno (Wright \& Zammuto, 2013).

(2) Condiciones referidas al entorno. Son aquellas que proveen al entorno de estabilidad, de manera que condicionan la posibilidad de que puedan tener lugar cambios. Destaca, entre ellas, 
la calidad de las instituciones de un país, de forma que éstas pueden ser débiles (ej. corrupción, marco regulativo inestable) o fuertes (ej. respeto a los derechos humanos, sistema juridicial eficiente), o bien ubicarse en algún punto intermedio entre estos extremos. La calidad de las instituciones es relevante porque las multinacionales turísticas tratarán de influir sobre su entorno cuando estos tienen instituciones débiles. Por ejemplo, pueden buscar intercambios que les permita enriquecerse tanto a ellas como a actores poderosos que preservarán las condiciones débiles existentes en el país (Acemoglu \& Robinson, 2012). Como consecuencia, el crecimiento de la industria turística en los países africanos en desarrollo, en ocasiones ha contribuido a acentuar las desigualdades existentes en la población local.

\section{Metodología: estudio de casos}

En el presente trabajo se hace uso de una metodología cualitativa basada en el estudio de un caso único que es analizado para examinar la relación entre una cadena hotelera española (en adelante HC) y las autoridades locales de un país africano. Estudiamos la evidencia proporcionada por una cadena hotelera que, en número de habitaciones en el extranjero, está entre las 5 más grandes de España. La empresa se estableció mediante inversión propia. El país, por su parte, representa uno de los mercados turísticos de más rápido crecimiento en África. HC ha localizado tres hoteles de 4 y 5 estrellas en el citado país.

Dado que este trabajo analiza la relación entre la multinacional hotelera y las autoridades locales, se consideró que los mediadores que participaron en la resolución del conflicto que surgió entre las partes podrían ofrecer información objetiva y, por lo tanto, válida, sobre las interacciones que tuvieron lugar entre ellas. El trabajo de campo se desarrolló en los meses de mayo y septiembre de 2014. Los nombres de los actores principales del caso, la cadena hotelera, los mediadores y el país de destino, se omiten debido a razones de confidencialidad.

\section{Resultados}

Retos afrontados por la multinacional para operar en el país africano en desarrollo

Los retos afrontados por HC para operar en el país africano son numerosos y diversos (Tabla 1). Tales retos, afectan no solo a esta empresa, sino a otras cadenas hoteleras establecidas en tal país.

Problemas afrontados por la multinacional para interactuar con las autoridades locales

Para los directivos españoles fue realmente difícil negociar y alcanzar acuerdos con el gobierno. El gobierno contaba con una clase élite de individuos que ocupaba puestos de alto nivel y había realizado sus estudios fuera del país, en Europa, Asia y/o Estados Unidos.

Tabla 1. Retos afrontados por HC para operar en el país africano según dimensiones del gobierno

\begin{tabular}{|c|c|}
\hline $\begin{array}{c}\text { Dimensiones del } \\
\text { gobierno }\end{array}$ & Problema específico encontrado por $\mathrm{HC}$ \\
\hline Efectividad del gobierno & $\begin{array}{l}\text { - Insuficientes servicios de salud básicos } \\
\text { - Red eléctrica (frecuentes cortes de suministro) } \\
\text { - Infraestructuras de transporte (incomunicados en ocasiones, } \\
\text { derrumbe de puente) } \\
\text { - Ineficiente transporte aéreo } \\
\text { - Sistema educativo insatisfactorio (carencia de fuerza laboral } \\
\text { cualificada) }\end{array}$ \\
\hline Calidad de la regulación & $\begin{array}{l}\text { - Falta de suministradores cualificados } \\
\text { - Tarifas discriminatorias (revisión del precio de las mercancías } \\
\text { incremento de costes de importación) } \\
\text { - Retrasos en las aduanas } \\
\text { - Impuestos discriminatorios (no devolución del IVA retenido) }\end{array}$ \\
\hline Imperio de la ley & - Probabilidad de crimen y violencia \\
\hline
\end{tabular}

Fuente: Basado en Kaufmann, Kraay y Mastruzzi (2010).

Los directivos españoles consideraban que la mejora de las infraestructuras básicas del país necesarias para llevar a cabo la actividad turística se produciría en paralelo con el desarrollo socioeconómico del país, de forma tal desarrollo beneficiaría tanto a la multinacional turística como a la población local. Sin embargo, cuando los directivos españoles acudían a reuniones con el gobierno para plantear sus problemas con las infraestructuras, solo recibían manifestaciones 
de buenas intenciones, sin que nada se hiciese por solventar tales problemas.

Por otra parte, el estilo de negociación era muy diferente al de las economías occidentales. Las negociaciones, muy lentas, avanzan poco y en ocasiones no se alcanza ninguna conclusión. Acorde a esta forma de proceder, las autoridades locales solían evitar ofrecer información sobre sus necesidades o sobre lo que ellos estarían dispuestos a ofrecer, y eludían asumir algún acuerdo al final de la reunión. En su lugar, citaban a HC para una reunión posterior bajo la que traerían las propuestas evaluadas. Sin embargo, la siguiente reunión comenzaría nuevamente con los locales cediendo la palabra a los españoles para que presentaran sus nuevas propuestas más elaboradas. De esta forma, el progreso en las negociaciones era extremadamente lento. HC experimentó esta forma de negociar y, poco a poco, aprendió a conocer el proceso.

Mecanismos utilizados para gestionar la controversia surgida

Aunque la relación entre HC y las autoridades locales nunca fueron sencillas, los conflictos se incrementaron cuando las autoridades locales cambiaron la forma de gestionar los fondos procedentes del Impuesto de Valor Añadido (IVA), que pasaron a no devolverse. HC oficialmente reclamó, pero el gobierno sistemáticamente evitaba dar respuesta a las reclamaciones de la empresa.

Como mecanismo alternativo para solventar el problema, HC pidió a las autoridades españolas que mediaran en el conflicto, pero el gobierno local no concedió una reunión a los representantes oficiales españoles. Las necesidades financieras del país africano (y no otras cuestiones tales como la corrupción) constituyen el factor que subyace a esta controversia, tema que nunca fue abordado por ambas partes. De hecho, la interacción estaba encallada porque una parte reclamaba su derecho y la otra, aún conocedora de este derecho, utilizaba la demora sistemática para evitar ofrecer una respuesta.

En un nuevo intento de resolver el problema, HC propuso a las autoridades del país africano renunciar a la devolución de sus fondos del IVA si, a cambio, las autoridades locales mejoraban las infraestructuras aeroportuarias en las regiones de interés para la empresa. Esto representa un primer intento de abordar el conflicto mediante mecanismos basados en la cooperación y/o la búsqueda del beneficio mutuo. Sin embargo, el gobierno rechazó esta propuesta ya que, en su opinión, HC estaba llevando a cabo una intromisión inaceptable en la toma de decisiones políticas y establecimiento de prioridades en el país.

Finalmente, HC fue consciente de su error en el manejo de esta controversia. HC tendría que haber identificado las necesidades de la población y las preocupaciones de las autoridades locales antes de establecer un diálogo con ellos sobre dónde invertir los fondos del IVA. Tal gesto por parte de la compañía habría sido apreciado por el Gobierno. Por ejemplo, cuando la empresa ha realizado donaciones a un centro de salud, el gobierno que ha manifestado su deseo de colaborar con la empresa.

Factores clave para interactuar con éxito con el gobierno local

El trabajo realizado muestra que la cooperación, más que la rivalidad es el mecanismo que parece poder culminar en una resolución exitosa de los problemas. No obstante, la cooperación es difícil de lograr. Nuestro trabajo identifica dos categorías de factores que condicionan la culminación con éxito del proceso de interacción. 
En primer lugar, y con respecto al país, la calidad de las instituciones es un factor muy relevante. En concreto, cuanto más fuerte son las instituciones, en mayor medida las multinacionales turísticas pueden esperar encontrar un marco institucional idóneo para la cooperación con las autoridades locales. Además, las actividades a acometer, tales como la negociación, dan lugar a un proceso complejo y dilatado en el tiempo, por lo que hay que prepararse para ello.

En segundo lugar, y con respecto a los actores implicados en el proceso, el hecho de que la empresa cuente con un nivel elevado de ciertas capacidades es relevante. Entre ellas, la empresa ha de contar con capacidad de aprendizaje, paciencia y disposición a afrontar problemas imprevistos o sobrevenidos en el país. Además, la responsabilidad social de la multinacional puede jugar un papel relevante en el proceso. De hecho, cuanto más socialmente responsable la empresa es, antes se alcanzará una comprensión de la perspectiva de las autoridades locales, ya que ambos compartirán probablemente una visión común sobre las necesidades sociales y económicas de la población del país.

\section{Conclusiones}

Las multinacionales turísticas interactúan con los gobiernos locales en los países en los que ellas operan. Esta interacción debe ser entendida como un proceso en el que las empresas pueden influir en sus entornos, pero estos, a su vez, también le afectan a ella.

En concreto, el caso estudiado pone de manifiesto que las interacciones cooperativas entre la multinacional turística y las autoridades locales pueden contribuir a garantizar el logro de beneficios para ambas partes. Esto es así porque las relaciones que se mantienen con la comunidad local puede afectar positivamente al desempeño (Inoue \& Lee, 2011).
Nuestros resultados también muestran cómo las diferencias en métodos y estilos de negociación pueden convertirse en uno de los retos más importantes para interactuar con los gobiernos en países en desarrollo. Asimismo, y dado que el proceso de negociación en estos países es complejo, duradero y consume mucho tiempo, diversas cualidades de los actores implicados tales como la capacidad de aprendizaje, la paciencia y la disposición a afrontar problemas sobrevenidos son de relevancia para alcanzar interacciones positivas y exitosas.

\section{Referencias}

Acemoglu, D., \& Robinson, J.A. (2012). Why Nations Fail: The Origins of Power, Prosperity, and Poverty. Crown Business: New York.

Brouder, P., \& Eriksson, R.H. (2013). Tourism Evolution: On the Synergies of Tourism Studies and Evolutionary Economic Geography. Annals of Tourism Research, 43, 370-389.

Fortanier, F., \& Wijk, J. (2010). Sustainable tourism industry development in sub-Saharan Africa: Consequences of foreign hotels for local employment. International Business Review, 19, 191-205.

Inoue, Y., \& Lee, S. (2011). Effects of different dimensions of corporate social responsibility on corporate financial performance in tourism-related industries. Tourism Management, 32(4), 790-804.

Kaufmann, D., Kraay, A., \& Mastruzzi, M. (2010). The Worldwide Governance Indicators: A Summary of Methodology, Data and Analytical Issues. World Bank Policy Research Working Paper No. 5430 URL: http://papers.ssrn.com/sol3/ papers.cfm? abstract_id=1682130 (Accessed on 18.01.2016).

Khavul, S., Chavez, H., \& Bruton, G.D. (2013). When institutional change outruns the change agent: The contested terrain of entrepreneurial microfinance for those in poverty. Journal of Business Venturing, 18(13), 30-50.

Madhok, A., \& Liu, C. (2006). A coevolutionary theory of the multinational firm. Journal of International Management, 12, 1-21. 
Wright, A.L., \& Zammuto, R.F. (2013). Creating opportunities for institutional entrepreneurship. Journal of Business Venturing, 28, 51-68.
Zhao, W., \& Ritchie, J. B. (2007). Tourism and poverty alleviation: An integrative research framework. Current Issues in Tourism, 10(2-3), 119143. 


\title{
Looking for fruitful interactions between tourism multinationals and local governments in Africa
}

\author{
Antonia Mercedes García-Cabrera ${ }^{\mathrm{a}, 1}$, Sonia María Suárez-Ortega ${ }^{\mathrm{a}}$, Juan José Durán-Herrerab \\ ${ }^{a}$ Universidad de Las Palmas de Gran Canaria (ULPGC), Spain \\ ${ }^{b}$ Universidad Autónoma de Madrid, Spain
}

\begin{abstract}
Studies on the internationalization of the developed-economy tourism industry towards developing economies commonly analyses the challenges that such activity entails for the parties involved -the foreign tourism business and the local community-from two distinct perspectives: (1) the specific challenges tourism MNCs face to successfully operate in an African country, and (2) the specific problems faced by local authorities and population because to Tourism MNEs activities. Being aware of the benefits of a fruitful relation between these two parties, we go beyond the isolated perspectives and try to answer the following questions: (1) what are the mechanisms available to tourism MNCs to interact with the local authorities and their possible effects? and (2) what are the key factors to successfully interact with government in Africa? We answer these question from the evidence of a case study.
\end{abstract}

Keywords: MNC, multinational firms, developing economies, Africa, tourism, firm-government interactions.

JEL classification: F23, N27, Z32.

Acknowledgements: Financial support from the Spanish Ministry of Economy and Competitiveness (Projects: ECO201341762-P; ECO2016-80518-R) is gratefully acknowledged.

Reference source: García-Cabrera, A.M., Suárez-Ortega, S.M., \& Durán-Herrera, J.J. (2016). Multinational corporations, coevolution, and sustainable tourism in Africa. European Journal of Tourism Research, 13, 23-42.

\section{Introduction}

Internationalization of the developedeconomy tourism industry towards developing economies is quite relevant for the tourism industry. Whereas some researchers have studied the challenges faced by foreign companies when entering and competing in institutionally weak economies, others have analyzed the damage in terms of social, cultural, and environmental sustainability generated by foreign tourism companies in the environments and societies of local communities. But the focus on either one of the two parties, risk being biased and could be insufficient in scope to respond to the challenges posed by such internationalization for both parties.

Indeed, real cases show evidence of controversial relationships between foreign businesses and local actors. On the one hand, MNCs can be blamed for the breakdown of relations with local authorities because of some questionable methods of operation and due to their relative superiority in terms of power. On the other hand, prior literature has also highlighted as major challenges facing foreign MNCs those related to host government intervention that affect both market-based and nonmarket-based competition, and the relationship with local government authorities.

As these discrepancies have been wellestablished over time, it is only fairly recently that governments and international organizations have been leaving these conventional views and started exploring the opportunities presented by a sustainable, 'pro-poor' tourism development (Fortanier \& Wijk, 2010).

${ }^{1}$ Corresponding author: antonia.garcia@ulpgc.es 
So, given that challenges for both parties coexist and that economic and business opportunities may emerge from a successful interaction between developed-economy tourism MNCs and local authorities in developing African countries (Zhao \& Ritchie, 2007), this study focuses on the processes and factors that condition such interactions. Certainly a better understanding of these processes would be useful to offer new practical guides in the areas of tourism MNCs’ management and public policy.

Accordingly, we aim at answering the following questions: (1) what are the specific challenges tourism MNCs face to successfully operate in an African country?; (ii) what are the specific problems faced when interacting with local authorities in a developing country?; (iii) what are the mechanisms used by tourism MNCs to interact with the local authorities and their possible effects?; and (iv) what are the key factors to successfully interact with governments in Africa?

\section{MNEs-government interactions and generic factors that affect them}

Companies and their environments may influence each other over time because there exist a bi-directional influence between companies' managerial decisions and the institutional environment (Madhok \& Liu, 2006). But, how the interactions take place between the parties and the key factors that condition such interactions are almost unknown.

According to the evolutionary principles, tourism companies' actions and practices, such as innovation and its transference between stakeholders, drives environment evolution over time (Brouder \& Eriksson, 2013). However, in contexts of adverse economic performance, companies in the tourism industry may have an incentive to actively promote changes in the environment that benefit them and so enhance their competitiveness.
In addition, companies may become involved in competing interactions to prevent undesired changes (Khavul, Chavez \& Bruton, 2013) attempted by host governments to combat their economic problems, if they believe these changes may negatively affect them.

Two main categories of conditions can be considered the cornerstones for these interaction processes:

(1) Actor-level conditions. They provide companies with resources to exert influence over the government. For example, firms' economic power and the profitability reached in the host developing country. In addition, some capabilities such as companies' flexibility to act and react when changes in the environment take place and the ability to mobilize the internal resources and external supports to respond to them are of relevance. Also, a company's ideology, such as social responsiveness and how it is prone to using its economic power bases to influence authorities, matter. Indeed, a company's ideology may affect the MNC's intention to exert influence over the government or to cooperate with it instead. In addition, MNCs also require social and negotiating skills to interact with local authorities since by themselves and as single actors they may fail to reach the attempted changes in the environment (Wright \& Zammuto, 2013).

(2) Field-level conditions. They provide stability or instability to the environment and so condition the possibility of changes. Among these conditions, the quality of institutions in a country is quite relevant. Institutions can be weak (e.g., corruption, instable and inefficient regulative framework) or strong (e.g., human rights are granted, rule of law, efficient judicial system), as well as being at a certain point between these ends of the interval. That is relevant because tourism MNCs may be more likely to exercise influence over the environment in cases where weak institutions exist. In tourist 
destinations where such weak institutions dominate, MNCs may be tempted to use their relevant power to influence local authorities in order to take advantage of these institutions. They may use the external exchanges to contribute to their own enrichment and that of the few other powerful actors that preserve the weak conditions existing in the country (Acemoglu \& Robinson, 2012). As a consequence, the growth of the tourism industry in the developing African countries has sometimes stressed inequalities among the local population.

\section{Methodology: Case study}

We apply a qualitative methodology based on a single and in-depth case study to examine the relationship between a Spanish hotel chain (HC) and local authorities in an African country. Specifically, we studied evidence from a top five Spanish hotel chain (in terms of numbers of rooms abroad) establishing itself in a given country in Africa, which is one of the fastest-growing markets for tourism among the highly tourism-based economies, according to the International Monetary Fund. HC has established three hotels of four and five stars in the African country under study.

As we examine the relationship between a foreign MNC and local authorities, we considered that mediators in the controversy between the parties, rather than companies' managers or local authorities that are part of the clash, could offer more objective and, therefore, more valid information. The field work took place in May and September 2014. Names of the main actors involved in the case (the hotel chain, the mediators and the country of destination), are omitted due to reasons of confidentiality.

\section{Results}

Challenges to successfully manage operations in the African country
The challenges faced by HC in their endeavors to operate successfully therein are numerous and diverse (Table 1). Such challenges affect not only to this company, but also any other hotel chain established in that country.

Table 1. Challenges faced by HC when operating in the given African country by dimensions of governance

Source: Based on Kaufmann, Kraay \& Mastruzzi (2010)

Specific problems faced when interacting with local authorities

For Spanish managers was really difficult to negotiate and reach agreements with the African government, where leading positions are occupied by highly trained elite comprised of locals that left the country to study in Europe, Asia and/or the USA.

Spanish managers considered that the development of the basic infrastructure needed to run the tourism sector and the socio-economic development of the country can occur in parallel, in a way that will benefit both the country's population and the tourism MNCs implanted there. However, Spanish managers attend meetings with local authorities and raised the problems with infrastructures, but all they receive were good intentions and finally nothing was done.

Additionally, the negotiation style in this developing country is very different from those common in occidental developed countries. Negotiations tend was very slow, with little advance and on numerous occasions do not reach 
a conclusion, with no explicit closing of them. According to this way of proceeding, local authorities usually avoid offering information about their needs or what they would be willing to offer, and evade assuming any agreement as a result of the meeting. They will then entice the other party to a subsequent meeting under the promise of assessing all proposals and delivering a pronouncement. But local authorities arrive at the next meeting and start it again by giving the floor to the Spanish managers so they can present their new and more elaborated proposal. In this way, very little progress is made with the negotiations. HC has experienced firsthand this form of negotiation with local authorities and has gradually learned to understand these processes.

Mechanisms used for handling a controversy over time

Although the relationship between the Spanish hotel chain and local authorities was not easy going in the early years in the country, conflicts were exacerbated when local authorities changed the way of managing funds from Value Added Tax (VAT). HC officially complained, but the Government permanently avoided the conflict.

In a new attempt, HC asked Spanish institutional representatives for mediation, but again the African authorities avoided the meeting. The real cause of the problem, which is the financial needs of the country (not others issues such as corruption), is not addressed in the conflict; in which a party claims the right, and the other, aware of this right, uses the delay to avoid giving an adequate response.

In a new attempt to solve the problem, HC proposed to the country's authorities renouncing the input VAT if they would use those funds to improve airport infrastructure in the country in areas of interest to the company due to the location of their hotels. This is the first approach towards a mutually beneficial cooperation.
However, the government rejected this proposal, as $\mathrm{HC}$ would be interfering in the political decision-making and the priority setting in the host country, which is considered inadmissible for the national government.

Eventually, HC became aware of its mistake in handling the controversy. HC should have identified the needs of the population and the concern of the local authorities as a prelude to dialogue with them about where to invest the VAT funds. Such a gesture by the company has been appreciated by the government that has expressed the desire to collaborate with the company.

Key factors to successfully interact with an African government

Our work shows that cooperation, rather than competition, between tourism MNCs and political actors in African countries is expected to culminate in positive and successful resolution of challenges. But this cooperation is rather difficult to reach. Our work identifies two categories of key factors that condition the successful culmination of the process.

First, and related to the country, the quality of institutions must be highlighted. In particular, the stronger the institutions are, the more tourism MNCs can expect to find an institutional framework suitable for cooperation with local authorities. In addition, the activities involved in the process, such as negotiating, result in the process being time-consuming and complex in these countries.

Second, and related to the actors involved, the existence of some relevant firms' capabilities are of high relevance. In particular, tourism MNCs' learning capabilities, patience, and readiness to deal with unforeseen conditions in the African country are of high relevance. So, it can be expected that the more the MNC has these capabilities, the easier and the sooner it will start 
to successfully interact with local authorities in order to achieve a positive relationship. In addition, MNCs' social responsibility can play a relevant role in the process. Indeed, the more socially responsible the company is, the earlier the understanding with local authorities will be reached as they both will likely share a common vision about the social and economic needs of the local population and the country.

\section{Conclusions}

This paper argues that tourism MNCs interact with their environments in the host countries where they operate and that this interaction must be understood as a process in which companies may affect their environments, but in turn are also affected by them.

We find that cooperative interactions between tourism MNCs and local authorities may contribute towards guaranteeing the achievement of benefits for both parties. It is because firmscommunity relationships will affect performance (Inoue \& Lee, 2011). Our findings also show how differences in negotiating methods can be one of the strongest challenges to interact with government in many developing countries. Also, as the process is time-consuming and complex in these countries, some qualities of the actors involved such as learning capabilities, patience and readiness to deal with unforeseen conditions are of high relevance for the successful interactions.

\section{Referencies}

Acemoglu, D., \& Robinson, J.A. (2012). Why Nations Fail: The Origins of Power, Prosperity, and Poverty. Crown Business: New York.
Brouder, P., \& Eriksson, R.H. (2013). Tourism Evolution: On the Synergies of Tourism Studies and Evolutionary Economic Geography. Annals of Tourism Research, 43, 370-389.

Fortanier, F., \& Wijk, J. (2010). Sustainable tourism industry development in sub-Saharan Africa: Consequences of foreign hotels for local employment. International Business Review, 19, 191-205.

Inoue, Y., \& Lee, S. (2011). Effects of different dimensions of corporate social responsibility on corporate financial performance in tourism-related industries. Tourism Management, 32(4), 790-804.

Kaufmann, D., Kraay, A., \& Mastruzzi, M. (2010). The Worldwide Governance Indicators: A Summary of Methodology, Data and Analytical Issues. World Bank Policy Research Working Paper No. 5430 URL: http://papers.ssrn.com/sol3/papers.cfm? abstract_id=1682130 (Accessed on 18.01.2016).

Khavul, S., Chavez, H., \& Bruton, G.D. (2013). When institutional change outruns the change agent: The contested terrain of entrepreneurial microfinance for those in poverty. Journal of Business Venturing, 18(13), 30-50.

Madhok, A., \& Liu, C. (2006). A coevolutionary theory of the multinational firm. Journal of International Management, 12, 1-21.

Wright, A.L., \& Zammuto, R.F. (2013). Creating opportunities for institutional entrepreneurship. Journal of Business Venturing, 28, 51-68.

Zhao, W., \& Ritchie, J. B. (2007). Tourism and poverty alleviation: An integrative research framework. Current Issues in Tourism, 10(2-3), 119143. 